\title{
A crônica e a representação do fato: o acontecimento cotidiano como construção social
}

\author{
Íris Vitória Pires Lisboa* \\ Juracy Assmann Saraiva**
}

\section{Resumo}

$\mathrm{O}$ artigo destaca o conceito de contrato de informação midiático, na crônica literária, a partir da representação do evento cotidiano. Objetiva demonstrar que o processo de elaboração e compreensão da crônica considera que $o$ leitor possa integrar ao universo representado no texto as suas construções de sentido sobre determinado fenômeno. A análise buscou reconhecer os sentidos construídos sobre o acontecimento noticiado no jornal, suporte para a construção literária. Constatou-se que o universo recriado na crônica resulta de um duplo processo de transformação, em que entram em jogo tanto o olhar do enunciador quanto a identidade do receptor.

Palavras-chave: Contrato de informação midiático; representação; crônica.
* Doutoranda em Processos e Manifestações Culturais (FEEVALE); Mestre em Linguística Aplicada (UNISINOS). Professora de Língua Portuguesa e Literatura (Fundação Liberato/NH. E-mail: iris@liberato.com.br

** Juracy Ignez Assmann Saraiva é graduada em Letras pela Universidade do Vale do Rio dos Sinos; Mestre em Literatura Brasileira pela Universidade Federal do Rio Grande do Sul; Doutora em Teoria Literária pela Pontifícia Universidade Católica do Rio Grande do Sul (1990) e realizou Pós-Doutorado em Teoria Literária, na Universidade Estadual de Campinas (2000). É professora e pesquisadora na Universidade Feevale, em Novo Hamburgo, e coordenadora do Mestrado Profissional em Letras, dessa mesma instituição. É Bolsista de Produtividade do CNPq, líder do Grupo de Pesquisa ?Ficção de Machado de Assis: Sistema Poético e Contexto? e participa do grupo Linguagens e Manifestações Culturais. Suas pesquisas na área de Letras concentram-se na obra de Machado de Assis, na leitura e na metodologia do ensino de literatura. Em 2011 recebeu o prêmio Pesquisador Destaque da Área de Letras do RS, concedido pela FAPERGS e instituições parceiras dessa Fundação. Entre suas publicações, constam "O circuito das memórias" (2009), obra sobre Machado de Assis, editada pela Edusp e Nankin, "Palavras, brinquedos e brincadeiras: cultura oral na escola" (2011), proposta de exploração da tradição cultural da oralidade nas séries iniciais do ensino fundamental, editado pela Artmed e "Texto Literário: Resposta ao desafio da formação de leitores" (2017), organizado juntamente com Ernani Mügge e Tatiane Kaspari, que se volta para a leitura de textos literários no ensino médio. Tem publicado inúmeros artigos, voltados para suas temáticas de pesquisa, em periódicos nacionais e internacionais, sendo orientadora de dissertações e de teses. E-mail: juracy@feevale.br

Data de submissão: abr. 2021 - Data de aceite: jul. 2021

http://dx.doi.org/10.5335/rdes.v17i2.11336 


\section{Introdução}

Este artigo aborda a ideia de contrato de informação midiático, desenvolvida por Patrick Charaudeau (2013), relacionada ao conceito de representação, de Stuart Hall (2016), a partir da análise de uma crônica da coletânea $O$ imaginário cotidiano (2002), de Moacyr Scliar. A proposta envolve dois conceitos significativos para os estudos sobre linguagem e se alia aos estudos sobre leitura, no tocante às questões linguísticas, discursivas e sociais implicadas na construção e interpretação do texto. Entende-se que uma abordagem dos elementos internos e externos ao texto contribui para uma melhor compreensão leitora.

Nessa direção, o principal objetivo desta análise é demonstrar que à ideia de contrato de informação subjaz um interessante jogo de intenções e estratégias, tanto por parte do enunciador quanto por parte do leitor da crônica, e que esse jogo é responsável pela construção de sentidos, processo envolvido em quaisquer interações sociais. O objeto de análise escolhido foi o texto "A casa das ilusões perdidas". A compilação de onde foi extraído o exemplar da crônica conta com uma organização peculiar: nela, o leitor tem acesso à manchete de jornal que serviu de base para a criação literária, o que viabiliza imaginar o percurso percorrido pelo cronista na construção do texto. A obra compreende 85 crônicas escritas a partir de notícias publicadas na Folha de São Paulo, durante os anos de 1998 a 2001. Após o título da crônica, consta a manchete da notícia-base e o dia de sua publicação, um aspecto importante para a contextualização do texto em seu espaço social, histórico e cultural.

Scliar escreveu crônicas para o jornal Zero Hora e Folha de São Paulo por mais de três décadas, o que aponta para uma representativa experiência com o gênero e para um sólido aporte para a consolidação da crônica como um texto breve, resultante de estratégias linguísticas e discursivas e de fácil acesso ao leitor. A escolha de um texto de sua autoria justifica-se por seu reconhecido talento como ficcionista, de produção quase diária, em um trabalho de recriação do real.

A análise descrita neste artigo fundamenta-se em três conceitos básicos: a noção de contrato de informação midiático (CHARAUDEAU, 2013), com ênfase nas representações presentes no acontecimento como visão social da realidade; o conceito de representação (HALL, 2016), pelo qual se atribui sentido ao mundo, sentido esse manifestado por meio da linguagem e que atua na construção do sujeito social; e a definição de crônica, gênero cuja origem remonta às narrativas históricas, passando pelo jornalismo e, finalmente, chegando à literatura, esfera em que seus aspectos característicos se consolidam, ganhando a simpatia dos leitores. 
A reflexão ancora-se na seguinte questão: partindo do pressuposto de que todo acontecimento é uma construção social, como a crônica (re)constrói o mundo noticiado pelo jornal? As respostas a essa problematização consideram elementos da constituição discursiva da crônica em diálogo com aspectos da identidade dos sujeitos instalados no ato de linguagem, na tentativa de mostrar que há uma espécie de contrato que organiza a relação entre os dados externos ao texto (a situação) e os dados internos (o discurso) e que atua na regulação das práticas sociais por meio dos diferentes discursos de representação.

Vislumbra-se, portanto, poder contribuir com o trabalho de leitura do texto literário, atentando para alguns de seus traços peculiares e destacando a responsabilidade não apenas do seu autor na construção dos sentidos, mas também do leitor, que, ao mesmo tempo em que busca compreender o texto, é influenciado por ele, constituindo-se como sujeito pelo discurso. Insere-se, portanto, a literatura nas discussões sobre a construção da identidade e do imaginário coletivo de uma sociedade, agregando valor à leitura e à arte como manifestação cultural.

Esta análise estrutura-se, pois, a partir de fundamentos teóricos e da subsequente verificação dos sentidos construídos sobre os acontecimentos noticiados no jornal, que serviram de base para o artefato verbal. Aponta-se, nas considerações finais, para a relação dialógica presente em todo ato de linguagem e para a possibilidade de se ampliarem os instrumentos e táticas de exploração do texto literário.

\section{A intersubjetividade no jogo da comunicação humana}

Partindo do pressuposto de que a enunciação tem natureza social, não existindo fora de um contexto (BAKHTIN, 1986), Charaudeau (2013) desenvolve seus estudos a respeito do contrato de informação midiático como

[...] um jogo de regulação das práticas sociais, instauradas pelos indivíduos que tentam viver em comunidade e pelos discursos de representação, produzidos para justificar essas mesmas práticas a fim de valorizá-las (p. 67).

Identificam-se nessa concepção dois pontos basilares da teoria de que se lança mão neste artigo: as construções discursivas e as práticas sociais. Em outros termos, os dados internos e externos ao discurso, que coexistem em função das diversas interações sociais tornadas possíveis pela linguagem.

Charaudeau (2013) define os dados externos como aqueles que indicam as regularidades comportamentais do indivíduo, não apenas as da linguagem, presentes em todo e qualquer ato de comunicação. Esses dados, conforme o 
autor, podem ser agrupados em quatro categorias, organizadas em função das condições de enunciação: condição de identidade, de finalidade, de propósito e de dispositivo.

A primeira condição diz respeito à identidade dos sujeitos inscritos no ato de linguagem e indica seus traços sociais e psicológicos, como sexo, idade, profissão, status social, autoridade, assim como alguns elementos do seu estado afetivo no momento da interação. Vale ressaltar que esses traços são significativos na análise discursiva se estiverem em uma relação de pertinência com o ato de linguagem, isto é, há traços identitários que são mais determinantes em algumas situações de comunicação do que em outras. Por um lado, a profissão exercida pelo sujeito que se depara com a notícia de um acidente, por exemplo, pode levá-lo a considerar diferentes aspectos, como é o caso de um médico e de um mecânico: este procuraria identificar as falhas no veículo causadores do revés; aquele, as consequências do impacto na estrutura física do indivíduo. Por outro lado, no que se refere à simples informação do ocorrido, a profissão do leitor de uma notícia pode não ser nada relevante.

Em diálogo com Charaudeau, Maingueneau (2009), ao tratar da cena de enunciação, recorre à imagem do ethos construído no discurso e afirma que este resulta da relação entre o ethos pré-discursivo e o ethos discursivo, sendo o primeiro relacionado à situação social real do sujeito, sua constituição como cidadão situado em um tempo e uma história; e o segundo construído no interior do discurso, direta ou indiretamente. Esses aspectos são relevantes na análise das identidades dos sujeitos envolvidos na enunciação, pois, além de contribuírem para sua construção, direcionam a compreensão textual para além dos elementos linguísticos, o que otimiza o trabalho de leitura.

Quanto à segunda condição, a de $f i$ nalidade, consideram-se os objetivos da comunicação, "[...] a expectativa de sentido em que se baseia a troca" (CHARAUDEAU, 2013, p. 69), que apontam para o conceito de visadas. Para Charaudeau, as visadas se referem à intencionalidade comunicativa e se dividem em visada prescritiva ("fazer fazer"), informativa ("fazer saber"), incitativa ("fazer crer") e a visada do páthos ("fazer sentir"). Dar-se-á ênfase, neste artigo, às visadas informativa - visto que o gênero em análise se constitui a partir do noticiário cotidiano, da notícia jornalística cujo intento é informar -, e do páthos - cujo intuito é sensibilizar o leitor.

Já a condição de propósito procura dar conta da questão "De que se trata?", e corresponde ao universo referencial da comunicação, no qual devem estar situados os interlocutores, sob risco de se verem "fora de propósito" e não conseguirem efetivamente se fazer en- 
tender. Marcuschi (2008) contribui com a discussão a respeito da condição de propósito ao definir a situacionalidade textual: esse critério trata da adequação do texto à situação de produção e recepção. Essa condição define estratégias que são importantes para que o texto tenha relevância numa dada situação, “[...] pois o texto figura como uma ação dentro de uma situação controlada e orientada" (MARCUSCHI, 2008. p. 129). Entende-se que Marcuschi, ao tratar desse aspecto da textualidade, amplia e corrobora o posicionamento de Charaudeau, que trata da noção de propósito, juntamente com as noções de universo de discurso e de acontecimento.

Por fim, a condição de dispositivo refere-se às circunstâncias materiais em que o discurso se constrói, ao ambiente em que "[...] se inscreve o ato de comunicação, que lugares físicos são ocupados pelos parceiros, que canal de transmissão é utilizado [...]". O dispositivo é um elemento determinante no interior de um ato de linguagem: uma mesma solicitação, feita face a face ou via e-mail pode ganhar nuances diferentes, mais ou menos formais, com maiores ou menores recursos de persuasão.

Para a análise que se propõe desenvolver aqui, as condições de identidade e de propósito ganham maior relevância, pois o objetivo é justamente mostrar como os traços identitários dos parceiros envolvidos na comunicação, desenvolvi- da no ato de leitura da crônica, interferem em sua compreensão, assim como identificar as representações construídas a partir dos acontecimentos cotidianos.

\section{A questão das identidades}

Todo ato de linguagem coloca em jogo duas esferas, a da produção e a da recepção. Aquela tem a responsabilidade de informar e provocar o desejo de consumir a informação; esta cumpre o papel de aceitar ou não a informação, de acordo com sua vontade e sensibilidade. Embora Charaudeau (2013) dê ênfase à comunicação midiática, é possível aplicar seu estudo ao tratamento do discurso literário, uma vez que os aspectos de seu trabalho são pertinentes a todos os campos discursivos, incluindo o da literatura. Um desses aspectos é que não há controle efetivo sobre o processo de construção e de recepção de um texto por parte dos parceiros envolvidos na comunicação.

Em se tratando da produção do texto, Charaudeau (2013) afirma que a instância produtora não apenas transmite a informação, mas constrói um saber a partir das representações de dado acontecimento. Isso significa que o leitor de um texto tem acesso não ao fato real, como ele ocorreu realmente, mas à representação que é feita a partir da visão e da sensibilidade daquele que o narrou. Recorre-se ao conceito de efeito 
de real, de Barthes (2004), na tentativa de ilustrar o processo de representação que constitui a informação: o real passa a ser significado dentro do texto, ele é reconstruído, pelos operadores de verossimilhança, que dão o caráter de realidade, embora estejam permeados de subjetividades.

Quanto à instância de recepção, não há como determinar se o público destinatário de um texto compactua com as representações construídas e se sensibiliza frente a elas a ponto de se deixar convencer ou emocionar. Por esse aspecto, Charaudeau (2013) desdobra a instância de recepção em duas: o destinatário-alvo e o receptor-público. Ao destinatário-alvo estão relacionadas as questões de compreensão, entendida como um mecanismo cognitivo dependente da capacidade do sujeito de produzir inferências interpretativas através de um jogo em que se relacionam o que é dito e o que já é sabido pelo sujeito. Já o receptor-público refere-se à motivação (conjunto de variáveis de desejos e necessidades psicológicas e sociais do indivíduo), ao querer, ao desejo que pode ser despertado durante o processo de interação.

Cabe, neste momento, retomar a caracterização dos sujeitos envolvidos em um ato de linguagem, proposto por Charaudeau (2012), em sua obra Linguagem e discurso. Para o autor, há dois sujeitos externos ao discurso e dois sujeitos in- ternos. Os sujeitos do mundo externo (Eu Comunicante e Tu Interpretante) são seres do universo real e carregam consigo suas identidades sociais, construídas em um determinado contexto histórico. Os sujeitos construídos no interior do discurso (Eu Enunciador e Tu Destinatário), por sua vez, representam sujeitos idealizados no ato de fala, que constroem a si mesmos e atuam para a construção dos sujeitos externos, ou seja, do Eu Comunicante e do Tu Interpretante. A relação entre esses sujeitos não é totalmente transparente, pois envolve estratégias e intencionalidades e também deve ser considerado que

[...] o mundo falado por estes sujeitos tem uma dupla representação, de acordo com a esfera em que se encontram: quando esse mundo é considerado no circuito da fala, corresponderá a uma representação discursiva; se ele for considerado no circuito externo, como testemunha do real, corresponderá a uma representação da situação de comunicação (CHARAUDEAU, 2012, p. 53).

Essa dupla representação é enfatizada na leitura da crônica desta análise que, por manter relação com o noticiário e apresentar a manchete jornalística que lhe deu origem, propõe ao leitor um movimento fluido, da crônica para a notícia, a fim de recolher no cotidiano pistas necessárias para entender as representações presentes na constituição discursiva.

Retornando à noção de contrato de informação, considera-se que este 
apresenta as condições para que se reconheçam os sujeitos envolvidos no ato de linguagem, a sua identidade social e a autoridade de fala que daí decorre e as estratégias de que o emissor lança mão a fim de garantir sua credibilidade diante de seu interlocutor.

\section{A questão do propósito}

Para tratar da condição de propósito, Charaudeau (2013) sugere ir além da noção de que o propósito é "aquilo de que se fala" e defini-lo como o "universo do discurso" que, para o linguista, configura-se como

O movimento da linguagem que, ao mesmo tempo em que está relacionado a um ato de troca, volta-se para o mundo para recortá-lo de uma maneira mais ou menos racional através das representações linguageiras e reconstruí-lo em categorias de sentido. Essa fragmentação semântica do mundo é ordenada por um ato de "tematização". Desse modo, o mundo-objeto é construído em objeto-sentido, o propósito, objeto de compartilhamento do ato de comunicação (CHARAUDEAU, 2013, p. 95).

O propósito, pois, abrange mais do que apenas o objeto de que se fala, visto que há uma construção de sentido em relação a esse objeto. Não há, portanto, a "transmissão" do mundo a ser comentado, mas uma "construção de sentido" por parte do enunciador e uma recepção que também não é neutra, pois compreende um interlocutor com identidade e intencionalidade próprias.
Charaudeau (2013) também dá destaque à ação da linguagem no processo de construção de sentido. Para o autor, a materialidade do mundo só ganha existência quando o sujeito manifesta, pela linguagem, o resultado da significação dada a ela. É pela linguagem que o indivíduo consegue expressar o sentido construído e compartilhá-lo com os outros. Da mesma forma, ao tratar um dado acontecimento pelo viés da subjetividade, o autor igualmente aborda a questão da alteridade, elemento presente na análise do texto literário: se o sujeito de linguagem é duplo, já que se desdobra em um eu e um tu que se constroem no discurso, também é duplo o "olhar que estrutura o acontecimento", isto é, entrelaçam-se o olhar de quem produz $o$ discurso e o olhar de quem o interpreta.

No sentido de ilustrar as questões sobre a representação do acontecimento, Charaudeau (2013) recorre aos estudos sobre a hermenêutica da narrativa, de Paul Ricoeur, que entende a narrativa por meio da mimese, desdobrada em três atividades: a mimese-1, uma pré-configuração do mundo (o fato observável, com certa autonomia); a mimese-2, uma configuração do mundo (como o mundo é constituído pelo sujeito enunciador); e a mimese-3, uma re-figuração do mundo (a interpretação do interlocutor).

Às atividades de mimese relaciona-se o último aspecto a se considerar sobre o contrato de informação no que se refere 
à condição de propósito: o acontecimento visto como um processo evenemencial (um evento). Embora o termo não seja tão usual, indica uma particularidade que pode ser tomada como síntese da condição de propósito e sua relação com o conceito de representação. Trata-se do processo de ordenamento do sentido pelos sujeitos, que "[...] integram suas percepções num sistema de experiência ou de pensamento que preexistem ao surgimento do fenômeno" (CHARAUDEAU, 2013, p. 99).

O processo evenemencial envolve três condições para que o sentido seja depreendido: a de modificação, mudança de um estado para outro ou desestabilização; a de percepção dessa modificação por um sujeito, sensível às alterações que a mudança provoca no mundo; e a de significação dessa modificação no mundo, isto é, recategorização semântica pela qual passará o fenômeno. A realidade narrada não é a realidade propriamente dita, pois, ao ser contada por alguém, é reconstruída, constituindo-se como um fragmento de uma realidade. Para que o acontecimento, o fato exista, ele precisa ser nomeado, precisa ganhar significado, o que é possível após o processo evenemencial em suas três etapas (CHARAUDEAU, 2013).

Esses são os fundamentos teóricos referentes ao contrato de informação que possibilitam a relação com as possibilidades de análise do texto literário, que se constitui, assim como todo ato de linguagem, a partir de múltiplas representações.

\section{Sobre o conceito de representação}

Outro importante ponto teórico para a análise de que resulta este artigo é o conceito de representação, proposto por Hall (2016). Procedente do campo dos Estudos Culturais, esse conceito ganha relevância nas discussões que envolvem linguagem e cultura. De acordo com Hall (2016, p. 31), "Representação é uma parte essencial do processo pelo qual os significados são produzidos e compartilhados entre os membros de uma cultura. Representar envolve o uso da linguagem, de signos e imagens que significam ou representam objetos". A construção do sentido, portanto, é o cerne da conexão entre o objeto, o sujeito e a linguagem. É a ele, o sentido, que os esforços de compreensão e compartilhamento são dirigidos a fim de justificar e manter as interações sociais em dada cultura.

Hall (2016) adota uma abordagem construtivista para tratar da linguagem, o que significa que é por meio dela que se constrói o significado. É pela conexão entre linguagem e conceitos que o indivíduo se refere ao mundo real ou imaginário. Para tanto, o autor aponta dois sistemas de representação: o primeiro deles é o sistema de conceitos e imagens formados na mente de cada indivíduo, relacionado 
a toda ordem de objetos, sujeitos e acontecimentos, inclusive àqueles que ele não vê e nunca verá e que só têm existência na imaginação. Sempre que deseja interpretar o mundo, fazer referência a ele, compartilhar alguma impressão ou sentimento, é a esses conceitos e imagens que o indivíduo recorre. Os integrantes de uma mesma cultura são capacitados para compreender os mesmos conceitos, interagindo por meio deles.

Esse compartilhamento, portanto, só é possível se também temos acesso a um outro (o segundo) sistema de representação em comum, a linguagem, que correlaciona os conceitos aos signos (palavras, sons ou imagens visuais).

O processo de significação na cultura ocorre, pois, a partir desses sistemas: inicialmente é preciso dar sentido ao mundo a partir de conceitos e imagens construídas mentalmente, para, então, esses conceitos serem transformados em signos compartilhados, processo ao qual Hall (2016) denomina representação.

É interessante observar que, embora os indivíduos de uma mesma cultura consigam compartilhar o mesmo sistema de conceitos e códigos, pelo menos de maneira geral, não há garantia de uma interpretação satisfatória e clara em todas as interações. Isso porque o sentido não está no objeto, na pessoa ou na palavra: ele é construído na interação. Hall (2016) afirma que
Essa "tradutibilidade" não é dada pela natureza ou fixada por deuses, mas é criada socialmente e na cultura, como o resultado de um conjunto de convenções sociais. [...] Pertencer a uma cultura é pertencer, grosso modo, ao mesmo universo conceitual e linguístico, saber como conceitos e ideias se traduzem em diferentes linguagens e como a linguagem pode ser interpretada para se referir ao mundo ou para servir de referência a ele (HALL, 2016, p. 42-43).

Ainda quanto ao sentido, destaca-se que, por ele ser resultado de uma construção social, cultural e linguística, não é fixado de forma definitiva, pois essas construções estão situadas em um tempo e um espaço e sofrem variações internamente e entre diferentes culturas. Entender essa espécie de dissolubilidade dos sentidos é importante na análise do texto literário. As diferentes práticas significantes, das quais a crônica é um exemplo, constroem e reconstroem sentidos por conta, muitas vezes, da subjetividade que lhe é peculiar. Ao ler diferentes crônicas, por exemplo, o leitor pode ter acesso a diferentes sentidos sobre o mesmo objeto.

A própria estrutura da coletânea que compõe o corpus desta análise já é um exemplo disso: a notícia no jornal revela a construção de sentido a partir do acontecimento; em seguida, o cronista refaz essa percepção, agregando novos sentidos ao discurso jornalístico e transformando, muitas vezes, o sentido original do acontecimento narrado. 
Chartier (1991) aborda o conceito de representação no âmbito da literatura, afirmando que ela se configura como prática simbólica, significante, pela qual o leitor tem acesso ao "fato", que é, sempre, uma representação, nunca o fato exatamente como ele ocorreu. $\mathrm{O}$ autor também discute a representação sob dois prismas: a representação como ausência, que sinaliza a diferença entre o que representa e o que é representado; e a representação como presença, uma vez que traz a público algo que não se faz presente de fato (CHARTIER, 1991).

Outra contribuição do historiador em relação à construção de sentido diz respeito ao suporte físico dos textos, o que é um aspecto relevante na análise da crônica em foco: inicialmente publicada em jornais, a crônica passa a conviver nos livros e isso, de acordo com Chartier (1991), interfere na maneira como será lida e interpretada, visto que se alteram, igualmente, os sujeitos receptores, assim como são diferentes os objetivos do acesso ao jornal e ao livro.

O processo de compreensão do texto literário, portanto, decorre da interação entre o sujeito produtor e o receptor do texto, ambos inseridos em sua esfera cultural, compartilhando signos através da linguagem, construindo-se a si mesmos como sujeitos e agindo na construção de novos sentidos para o que é vivido.

O terceiro e último conceito refere-se à noção de crônica como um gênero híbrido, que se situa entre o jornalismo e a literatura, e que tem na obra de Moacyr Scliar um exemplo do profícuo diálogo entre essas duas esferas. Seus aspectos característicos serão retomados ao longo da análise da crônica escolhida.

\section{O contrato e a crônica: novos olhares para o texto}

Partindo da teoria sobre o contrato de informação midiático e do conceito de representação, passa-se à análise da crônica "A casa das ilusões perdidas", que integra a coletânea $O$ imaginário cotidiano (2002), de Moacyr Scliar. A manchete que a precede é a seguinte: "Polícia investiga troca de bebê por casa" (Cotidiano, 10 jun.1999). A crônica foi publicada dia 14 de junho, do mesmo ano, no caderno intitulado Cotidiano.

\section{A casa das ilusões perdidas}

Quando ela anunciou que estava grávida, a primeira reação dele foi de desagrado, logo seguida de franca irritação. Que coisa, disse, você não podia tomar cuidado, engravidar logo agora que estou desempregado, numa pior, você não tem cabeça mesmo, não sei o que vi em você, já deveria ter trocado de mulher havia muito tempo. Ela, naturalmente, chorou, chorou muito. Disse que ele tinha razão, que aquilo fora uma irresponsabilidade, mas mesmo assim queria ter o filho. Sempre sonhara com isso, com a maternidade - e agora que 0 sonho estava prestes a se realizar, não deixaria que ele se desfizesse. 
- Por favor, suplicou. - Eu faço tudo que você quiser, eu dou um jeito de arranjar trabalho, eu sustento o nenê, mas, por favor, me deixe ser mãe.

Ele disse que ia pensar. Ao fim de três dias daria a resposta. E sumiu.

Voltou, não ao cabo de três dias, mas de três meses. Àquela altura ela já estava com uma barriga avantajada que tornava impossível o aborto; ao vê-lo, esqueceu a desconsideração, esqueceu tudo - estava certa de que ele vinha com a mensagem que tanto esperava, você pode ter o nenê, eu ajudo você a criá-lo.

Estava errada. Ele vinha, sim, dizer-lhe que podia dar à luz a criança; mas não para ficar com ela. Já tinha feito o negócio: trocariam o recém-nascido por uma casa. A casa que não tinham e que agora seria o lar deles, o lar onde - agora ele prometia - ficariam para sempre.

Ela ficou desesperada. De novo caiu em prantos, de novo implorou. Ele se mostrou irredutível. E ela, como sempre, cedeu.

Entregue a criança, foram visitar a casa. Era uma modesta construção num bairro popular. Mas era o lar prometido e ela ficou extasiada. Ali mesmo, contudo, fez uma declaração:

- Nós vamos encher esta casa de crianças. Quatro ou cinco, no mínimo.

Ele não disse nada, mas ficou pensando. Quatro ou cinco casas, aquilo era um bom começo.

Revolta e indignação talvez sejam os sentimentos que afloram mais fortemente durante a leitura do desenlace do texto. Não se vislumbra possibilidade alguma de compartilhamento entre os desejos e interesses dos personagens. $\mathrm{E}$ o senso comum em relação ao sagrado da maternidade e ao valor dado à vida levam o leitor a condenar a troca do bebê, atitude incompatível com a ideia de humanidade.

Candido afirma que a literatura é uma necessidade do homem, pois é ela que nos "humaniza" pela possibilidade de "dar forma aos sentimentos e à visão de mundo" (CANDIDO, 1992). A arte literária reconstrói o mundo a partir de sua representação, dando-lhe novo sentido.

Dentre os gêneros literários, a crônica participa da constituição da consciência de tempo e espaço por parte de seu leitor pela proximidade com as práticas sociais do cidadão comum. Para Candido (1992), a crônica conquistou, por sua simplicidade, um espaço de prestígio no universo literário brasileiro, por sua leveza e acessibilidade e por comunicar "mais do que um estudo intencional a visão humana do homem na sua vida de todo o dia" (CANDIDO, 1992, p. 19). A crônica literária conecta-se à ideia de representação e de imaginário coletivo, uma vez que se caracteriza pela relação que mantém com o cotidiano das pessoas e por sua forma de lidar com os fatos sociais.

Nessa crônica, Scliar apresenta ao leitor uma situação fictícia criada a partir de uma notícia publicada em um jornal de grande circulação em São Paulo. Nela, um casal, tão diferente em suas vontades 
e desejos, encontra-se em situação de extrema pobreza, causada, em grande parte, pelo desemprego do homem. A história inicia com a informação de que a mulher está grávida. O plano de não ter que criar o filho e ao mesmo tempo lucrar com isso é atrativo ao pai, que o coloca em prática, pensando em ampliar os lucros com a troca de bebês, como é indicado ao final do texto.

Esta crônica permite que se apontem elementos da teoria a respeito do contrato de informação (CHARAUDEAU, 2013), colocando em discussão as intenções e estratégias por parte do enunciador e do leitor da crônica. E é em relação aos sujeitos envolvidos nesse contrato que a análise se organiza inicialmente.

$\mathrm{O}$ sujeito produtor do ato de enunciação é o cronista Moacyr Scliar e o sujeito receptor é o leitor da crônica, que coincide, inicialmente, com o leitor do jornal Folha de São Paulo (quando publicada em livro, o sujeito receptor passa a ser um leitor um pouco mais específico, interessado por crônicas e por literatura). Scliar não tem acesso ao perfil desse possível leitor, mas é provável que este saiba algo sobre Scliar, que já era conhecido como escritor de literatura quando iniciou o trabalho como cronista na Folha. Sua identidade como escritor sempre esteve muito relacionada ao exercício da medicina, o que lhe dá certa autoridade para falar das mazelas humanas, assim como atribui ao autor uma atitude de empatia e solidariedade. As características de sua identidade social relacionam-se, portanto, às de sua identidade discursiva: como enunciador, cria-se um sujeito preocupado em mostrar que os desejos das personagens não são os mesmos e, pela maneira como o pai é apresentado, o enunciador tende a fazer com que o leitor se convença de que a troca dos bebês por casas vai além do desespero decorrente da miséria e da fome.

Percebe-se, neste ponto, a defesa de uma tese no texto do cronista: muitas vezes, o que pode ser justificado como um ato de sobrevivência, é apenas mais uma demonstração de ganância. Há limites para as atitudes humanas. Quando o homem é capaz de transpor valores sociais tão fortes, como é o caso da paternidade, não há justificativas suficientes. Ao concluir o texto com a ideia de novas trocas para conseguir mais casas, tanto o sujeito comunicante quanto o enunciador, isto é, aquele sujeito construído discursivamente, parecem condenar a atitude do personagem e assumem a posição de condenação também no que se refere ao fato real noticiado na Folha.

Nesse sentido, a construção da crônica ilustra o que Charaudeau (2013) trata como processo evenemencial: ao narrar uma situação (fictícia ou real), o autor propõe uma visão de mundo não apenas constativa, mas explicativa, isto é, à medida que conta o fato, o enunciador se posiciona em relação a ele. A problematização do fato e a tomada de posição são "motores" para a construção de sentido 
sobre o que é narrado e, embora contar o fato seja diferente de comentá-lo, ambas são atividades intrinsicamente ligadas no discurso (CHARAUDEAU, 2013).

Charaudeau, ao tratar dos gêneros midiáticos, afirma que a informação e a captação são instâncias que se complementam e se retroalimentam: "Um não existe sem o outro, pois o que justifica que se fale dos fatos é que se faça um comentário a respeito" (CHARAUDEAU, 2013, p. 91). Percebe-se essa conexão também na crônica, e em especial na construção dos textos da coletânea em questão: pelo fato de os textos terem sido publicados inicialmente no jornal, relacionados a notícias anteriores, pode-se afirmar que há um "reforço" da informação na crônica de Scliar, em que o cronista mostra o que aconteceu ou imagina o que poderia ter acontecido e vai além disso, revelando "o que não se vê", o que emociona, o que faz pensar, o que provoca a reflexão sobre o acontecimento.

A crônica objetiva, de certo modo, informar o leitor e persuadi-lo a se inteirar dos acontecimentos, buscando traços de verossimilhança no que é narrado. Para o autor, "Tornar verossímil é tentar fazer crer que o relato corresponde à reconstituição mais provável, apresentando-se o dito como o mais fiel possível ao fato tal como se realizou" (CHARAUDEAU, 2013, p. 89). Além disso, também busca provocar reflexões e posicionamentos a partir dos "mapas conceituais" comparti- lhados entre os membros de uma mesma cultura, manifestados pela linguagem, o que constitui o processo de representação (HALL, 2016). Para Hall (2016), uma abordagem construtivista para explicar a representação do sentido pela linguagem entende o sentido como algo construído socialmente. Para o autor, os significados não são fixos no mundo material nem são inerentes aos sujeitos, mas construídos pelos sistemas de representação.

Construtivistas não negam a existência do mundo material. No entanto, não é ele que transmite sentido, mas sim o sistema de linguagem, ou qualquer outro que usemos para representar nossos conceitos. São os atores sociais que usam os sistemas conceituais, o linguístico e outros sistemas representacionais de sua cultura para construir sentido, para fazer com que o mundo seja compreensível e para comunicar sobre esse mundo, inteligivelmente, para outros (HALL, 2016, p. 48-49).

A ideia de "mapas conceituais compartilhados" se faz presente também nas reflexões de Candido (1992), quando este afirma que "[...] a crônica está sempre ajudando a estabelecer ou restabelecer a dimensão das coisas e das pessoas", e o faz com um olhar atento ao "miúdo" do dia a dia, que lhe serve de matéria-prima para a reescrita das experiências de vida do cronista e dos leitores. Esse novo olhar do cotidiano proposto pela crônica é, na verdade, a construção de um novo sentido dado à vivência do cronista, compartilhado com os leitores, que provoca neles o repensar sobre a sua própria existência. 
Na crônica "A casa das ilusões perdidas", o conceito de maternidade e os valores ligados a ele opõem-se à ideia de aquisição material. Ter um bebê e ter uma casa são desejos opostos, que, pela miséria em que se encontram os personagens, não podem ser atendidos sem que um anule o outro. A ambição do homem se impõe à força da agressão verbal (que supõe a agressão física pelas construções do imaginário social de uma sociedade machista), mas não anula o desejo da mulher de ser mãe. Ela, ignorando os reais propósitos do marido, volta a desejar os filhos, ainda mais fortemente, pois agora eles têm uma casa onde abrigá-los.

A representação de maternidade que permeia o imaginário coletivo constitui um valor sublime, quase divino: ter um filho é sinal de nobreza de sentimentos e de altruísmo. Nada pode ser maior que isso. Considerando a figura feminina na sociedade contemporânea, embora muitas mulheres não tenham vontade de ser mães, ainda se olha com desconfiança para casais que, após um tempo de relacionamento, não se tornaram pais. Essa é uma das situações apresentadas na crônica que objetiva comover o leitor e acaba criando um julgamento negativo a respeito da atitude do homem, que não realiza o sonho da parceira, eliminando sua ilusão em troca da casa.

Há um aspecto a se considerar, porém, que pode suscitar outra emoção no sujeito destinatário: o que se revela na crônica não é apenas a maldade do homem em relação ao desejo da mulher, mas a situação de miséria em que os dois estão inseridos. Considerando as palavras de Hall (2016, p. 22), "Os sentidos também regulam e organizam nossas práticas e condutas: auxiliam no estabelecimento de normas e convenções segundo as quais a vida em sociedade é ordenada e administrada". O fato de uma mulher não realizar o desejo de ser mãe pode ser mais revoltante do que um casal não ter condições básicas para a subsistência. Essa situação realça certos mapas conceituais da atualidade, resultantes de circunstâncias desumanizadoras, que levam ao apagamento dos desejos, das vontades e das necessidades de cada um.

O desenlace da crônica também sugere que o sujeito contemporâneo se espanta com a possibilidade de uma mãe não assumir o filho gerado, principalmente se isso não for uma decisão dela, e que a miséria e a fome são, muitas vezes, resultados de uma atitude de acomodação e desleixo. Uma sociedade que se identifica com os princípios da meritocracia é capaz de avaliar o que é narrado na crônica de Scliar como consequência de um livre arbítrio. Nas construções de sentido que formam o imaginário social, a mulher deve ter filhos e o homem deve prover o sustento da família. Quando essa situação não é garantida, o desequilíbrio é culpa de escolhas individuais. 
Retomando Hall (2016, p. 23), "O sentido é um diálogo - sempre parcialmente compreendido, sempre uma troca desigual”. Não há somente um sentido a ser depreendido do texto. Considerando-se a notícia-base que deu origem à crônica, pode-se analisar outra condição de enunciação proposta por Charaudeau (2013), a condição de propósito. Entende-se que, quando o cronista faz o "recorte" de uma notícia publicada em jornal e constrói seu texto, no âmbito da literatura, ele altera o propósito inicial. De acordo com o linguista, o discurso

[...] abarca os acontecimentos do mundo, mas estes só ganham sentido por meio de uma estruturação que lhes é conferida pelo ato de linguagem através de uma tematização (CHARAUDEAU, 2013, p. 95).

Logo, mesmo que o acontecimento tenha passado pelo filtro do contrato midiático, ao se tornar crônica, novos sentidos lhe são atribuídos em razão do "olhar que se estende sobre ele, olhar de um sujeito que o integra num sistema de pensamento e, assim fazendo, o torna inteligível” (p. 95).

Esses novos sentidos não são controlados pelo enunciador, não há como prever que possíveis relações o leitor fará com a sua própria realidade, com seus "mapas conceituais" a fim de dar sentido ao que lhe é contado. Tanto o discurso midiático quanto o literário possuem esta característica: para além do fato, do acontecimento do mundo real, há configurações que o modificam, que o tornam uma representação da realidade, por parte do sujeito enunciador que configura o mundo ao narrá-lo e do sujeito interpretante, que realiza uma re-configuração desse mundo durante a leitura.

O novo propósito, portanto, deve ser compartilhado com o sujeito destinatário, aquele idealizado na construção discursiva. Além disso, esse sujeito deve ter clareza da mudança de dispositivo pelo qual o acontecimento passou. Pode-se dizer que há, junto à mudança de dispositivo, a mudança de visada, ou a ênfase em uma nova visada: no livro, a crônica desvincula-se da notícia de forma mais natural e seu objetivo passa a ser sensibilizar o leitor para a situação narrada, captar suas emoções e seu julgamento.

Essa modificação do acontecimento, portanto, e a subsequente percepção dessa mudança é o que Charaudeau (2013) chama de processo evenemencial e pode ser relacionada ao que Hall (2016) conceitua como representação, ambos processos de construção de sentido que dependem tanto das configurações dos sujeitos envolvidos na comunicação quanto do contexto em que ocorre o discurso. Na crônica em questão, a troca de bebês por casas deixa de ser um caso de polícia para ilustrar as mazelas sociais de que são vítimas os indivíduos das grandes cidades. No último parágrafo da crônica, quando o enunciador se refere ao personagem, dizendo que "Ele não 
disse nada, mas ficou pensando. Quatro ou cinco casas, aquilo era um bom começo", sugere-se que acima da maldade humana, dos desejos humanos e do afeto partilhado, está a ambição do homem e sua vontade insaciável de acumular riqueza. $\mathrm{O}$ olhar do cronista recupera algo que estava nas entrelinhas do acontecimento, dando-lhe novo sentido.

Esse procedimento é recorrente na crônica. A construção pitoresca do que é simples, a simplicidade com que trata o dia a dia ou a complexidade com que reconstrói o que parece tão banal são estratégias de construção textual desse gênero que, conforme cita Candido (1992, p. 20), “[...] pode dizer as coisas mais sérias e mais empenhadas por meio do ziguezague de uma aparente conversa fiada”.

A crônica, portanto, essa "aparente conversa fiada”, constitui-se de estratégias de construção de sentido que não modificam apenas a forma de olhar o cotidiano, mas também transformam o próprio sujeito diante do mundo.

\section{Considerações finais}

A presente análise caracterizou-se pela retomada de preceitos teóricos advindos dos estudos de Charaudeau (2013), no que se refere ao contrato de informação midiático, e do conceito de representação, de Hall (2016), aplicados na investigação da crônica literária, com ênfase na representação do cotidiano como construção social.

A relação entre os conceitos e a crônica "A casa das ilusões perdidas", de Moacyr Scliar (2002), permitiu observar que os sentidos construídos pelo sujeito enunciador nem sempre apresentam simetria quando recebidos pelo sujeito destinatário, o que aponta para a influência de questões subjetivas no processo de significação. $\mathrm{O}$ acontecimento cotidiano representado no texto, ao ser interpretado pelo leitor, passa a receber novos elementos, que encaminham a sua compreensão para um conjunto de valores e conceitos relacionados às identidades dos parceiros envolvidos no ato de linguagem.

É importante assinalar que a análise do texto de Scliar não se esgota no exercício que aqui se promoveu, pois, pelo fato de o objetivo deste trabalho ter como foco a relação entre os estudos de Charaudeau e Hall, há aspectos que não foram contemplados, como é o caso dos elementos propriamente discursivos, referentes ao projeto de fala. Optou-se, portanto, por explorar certas condições de enunciação, a fim de identificar algumas regularidades comportamentais dos sujeitos que participam do evento comunicativo (CHARAUDEAU, 2013).

Aspira-se, pois, ter colaborado com os estudos acerca das questões discursivas e com os estudos sobre a crônica, tendo como eixo central o conceito de representação, que permite que se integrem 
linguagem, sentido e cultura na interpretação do texto literário, entendendo a leitura como "uma atividade sistemática que parte do nível da expressão linguística e da concepção estrutural do texto para evidenciar os elementos que ferem a percepção imagética do leitor e a ele possibilitam instituir a significação textual" (SARAIVA, 2006, p. 36). Falar em atividade de leitura na escola, portanto, pode ir muito além da decodificação de sinais gráficos, provocando descobertas sobre o mundo e sobre o próprio sujeito.

\section{Chronicle and fact representation: the everyday event as a social construction}

\section{Abstract}

The article highlights the concept of media information contract, in the literary chronicle, from the representation of the everyday event. It aims to demonstrate that the process of elaborating and understanding the chronicle considers that the reader can integrate his constructions of meaning about a given phenomenon into the universe represented in the text. The analysis sought to recognize the meanings constructed about the event reported in the newspaper, support for literary construction. It was found that the universe recreated in the chronicle results from a double transformation process, in which both the enunciator's gaze and the recipient's identity come into play.

Keywords: Media information contract; representation; chronicle

\section{Referências}

BAKHTIN, Mikhail. Marxismo e filosofia da linguagem. São Paulo: Hucitec, 1986.

BARTHES, Roland. O efeito do real. In: O rumor da língua. São Paulo:

Martins Fontes, 2004. P. 181-190.

CANDIDO, Antonio. A crônica: o gênero, sua fixação e suas transformações no Brasil. Campinas: Unicamp; Rio de Janeiro: Fundação Casa de Rui Barbosa, 1992.

CHARAUDEAU, Patrick. Linguagem e discurso: modos de organização. São Paulo: Contexto, 2012.

Discurso das mídias. São Paulo: Contexto, 2013.

CHARTIER, Roger. O mundo como representação. Estudos Avançados, v. 5, n. 11, p. 173-191, 1 abr. 1991.

HALL, Stuart. Cultura e representação. Rio de Janeiro: PUC-Rio/ Apicuri, 2016.

MAINGUENEAU, Dominique. Discurso literário. São Paulo: Contexto, 2009.

MARCUSCHI, Luiz Antônio. Produção textual, análise de gêneros e compreensão. São Paulo: Parábola Editorial, 2008.

SARAIVA. Juracy Assmann. Por que e como ler textos literários. In: SARAIVA, Juracy Assmann; MÜGGE, Ernani. Literatura na escola: propostas para o ensino fundamental. Porto Alegre: Artmed, 2006. p. 27-44.

SCLIAR, Moacyr. O imaginário cotidiano.

São Paulo: Global, 2002. 